\title{
The Harmonization of Dakwah and Politics of Constitutional Law
}

\author{
Paisol Burlian \\ Lecturer of Da'wah and Communication Faculty The Raden Fatah State Islamic University \\ Corresponding Email:burlianpaisol@yahoo.co.id
}

\author{
Article history \\ Received: 2015-12-02 \\ Received in revised form: 2016-11-22 \\ Accepted: 2016-11-17
}

\begin{abstract}
It is undeniable that Islam is a universal religion which becomes a blessing for the entire universe. Universality of Islam is evident from multi-aspect, a religious aspect, set the life of mankind, and included the inside of preaching and political aspects of constitutional law. This paper examines how, in practice, where the Prophet Muhammad has implemented a law in constitutional politics in line with the guidance of the Quran, especially the Medina period. When in Mecca, the Prophet, as a religious figure, shows preaching secretly and finally in open way. However, in Medina, It is clearly seen that there is an integration of the Prophet Muhammad as the religious figure and statesman. While the Prophet still spreads preachings, the Prophet set the Medina becoming a developed country and then Islam can be spread to the world. Today, Islam has become strength and principles which is believed and practiced by the world's population and it is inseparable from the role of preaching and politics. Both of them are integrated and connected together in the history of Islam as well as in conception and implementation. To keep the existence of Islam, the role of preaching and politics of constitutional law must be optimized for the future. Their relationship, ideally demonstrated that politics serve as a tool to carry out the mission of preaching. On the other hand, the preaching must also be able to provide an understanding of the political importance of constitutional law for the advancement of religion and the Muslims and not vice versa; stay away from politics because of the wrong perception or manipulate the preaching for political purposes of constitutional law. To ensure that the constitutional law of political activity is not lost, it should be understood that in the politics of constitutional law, there is a law that must be followed, whereas in law, there are the political aspects of constitutional law should be implemented. It will create synergy between preachings and politics of constitutional law for the realization of the Islam's glory in national as well as in international.
\end{abstract}

Keywords: Harmonization, Preaching, and Politics of Constitutional Law. 


\subsection{INTRODUCTION}

The existence of the Islamic preaching takes a strategic position. Preaching serves as the reconstruction of Muslim society in accordance with the ideals of the Islamic social institutions through the teachings of Islam as a universal grace. Socialization Islam through preachings is expected to allow the process of Islamisation's values, so it is lived and practiced by individuals, families, communities and countries for the peacefulness of the human world and the hereafter. That thought places preaching as a large and important programs or azmil umur (Q.S. Lukman [31]:17).

Therefore, this preaching requires the involvement of all Muslims in various professions and skills, including rulers and politicians. History records that Islam has successfully managed to build a great civilization which is recognized by the Islamic world and to become a world power and it cannot be separated from the influence of preaching and politics. Islamic civilization from the time of the Prophet Muhammad to the present day cannot be separated from these two things. It can be said that the reciprocation of the Islamic community is strongly influenced by strength of preaching and politics of Islam. However, in the course of Islamic history, preaching and political issues have become a serious concern. Some preachers assume that preaching and politics should not be separated in the Islamic society, while others assume that the politics and preaching are strongly opposed and cannot be combined each other.

Today, the different views are still frequently encountered in the middle of the society. Opinions, thoughts and negative prejudice are shown especially in politics which is considered something that does not give much benefit in the society. On the other hand, preaching has been positioned as a sacred activity which becomes the legacy of the prophets and should not be combined with politics. These phenomena have long been embedded in the minds of our society, so that it is very appropriate if Hasan Al Banna revealed that only few people talk about politics and Islam, unless he separates between them and places each one independently. Both are not possible being together and reunited. On the other hand, some Islamic organizations engaged in preaching explicitly states that the organization is not political. However, in a real practice, it always keeps contact and has political dimension. (Taufiq Yusuf Al-Wa'iy, 2003: 39)

That phenomenon indicates that some people in society have lack of understanding toward the functional relation between preaching and politics. Generally, society considers that the preaching should not be interfered by politics, and politics should not be in the name of preaching. This thought impresses that politics is something that is dirty, full of hypocrisy, deceit, cunning, and justifies any means to achieve the goal. Political figures only close to the people just before the general elections. While preaching is positioned as a noble activity to provide guidance in accordance with the demands of Islam, so it can not be located by politics. (Amien Rais, 1991: 23)

That such understanding is very reasonable because it is based on existing experience. In reality, the arena of politic is always tinged with the negative image in the view of society. While the topic of preaching does not always touch politic. The preaching talks a lot in aspects of worship, forbidden things and hereafter's life as well as the things that connect to Khilafiyah and diversity in worship. Preaching in term of political aspect tends to be ignored, while Islam as mentioned above is a universal teaching that involves all aspects of human life, and as confirmed by Hasan Al Banna that Islam is a universal system that is complete and covers all aspects of human's life (Hasan al-Banna, 1983: 69).

It is true that the practice of politics and preaching in society must be understood and depicted as two sides of a coin. They complement each other, and are not considered perfect if one of them does not exist. This means that the preaching and politics can not be separated, but can be distinguished. This paper will try to uncover the extent of preaching and politic's relations that become an important portion of Islam's teaching and glory 
Besides, Islam adheres to the principle of unity between religious and world case. That is, the two must go hand in hand because they both come from the same Creator. Islamic religion was formulated by God, and world affairs use the human's mind, the two are not necessarily met. There are two duality of interest. The problem is, human interests are identical with superficial analysis, influenced by emotions that will even become lust. While the interests of God are framed by all-perfect nature; fair, thoughtful, complete, not a burden, transcends time, across generations, across ethnic and racial and perfectly covers all life's questions of human.

Secularism is not recognized in Islam. Secularism is as same as ignoring Allah in terms of world arranging and considers Islam as an incomplete thing because it can only manage the affairs of the hereafter. Secularism is as unbeliever as communism, democracy, Hindus, Buddhists, Christians, Jews, and other heathens.Prophet as an ideal figure in translating Islamic theory in the real world becomes the first to exemplify the concept of unity between religion and the world. Islam and democracy are not only compatible; on the contrary, the association of both is inevitable, because the political system of Islam is based on the Shura (consultation) ( Syarifuddin Jurdi, , 2006:48).Prophet became head of state as well as a prophet, the combination of the top two positions at each.

World's highest career is becoming a president and the highest maqom of Shari'a is the position of a prophet. All such positions of Shari'a like scholars, muftis, mujahid, qodhi, clerics and so on are under a prophet's position. (Ibnu Taimiyah, 1969:64).

This fact signals that Islam can be combined with the world, or the paradigm of faith; Islam should be displayed together with the world setting. If reality has not revealed such facts, it should strive to blend, as shown by the Prophet during his lifetime. So that the short answer to the question, "how Islam governs the relationship between the politic and Shari'a" is both should be merged into one management and leadership; Court to hear Shari'a as well as the court to hear the world'scase. Reference of case law in Shari'a is Quran and As Sunnah and this same reference should be used for the affairs of the world.

There are regulations of intimate parts when implementing Shari'a, and also when working in banks, offices and exercises. There are no terms in religious and state courts. There should be no fashion rules when praying, but there are other rules when playing volleyball or gymnastics (referring to informal international agreements). Is there a standard provision that the woman playing volleyball only allowed to wear pants and tight shirts?

The requirement to hold the country's politic with Shari'a is a historical fact at the time of the Prophet and the caliphs that can not be denied. What we need to examine further is how if the political state is not regulated by law, like the case today? What is the ruling? How do we as people put away? What is our obligation? How is the solution? And so on.

Propositions which require political unification with the state law are as below: (An-Nisa: 60) Hast thou turned Thy thought to those who declare that they believe in the revelations that have come to thee and to those before thee? Their (real) wish is to resort together for judgement (in their disputes) to the Evil (Tagut), though they were ordered to reject him. But Satan's wish is to lead them astray far way (from the right).

This verse describes the faith denial of someone if they deliberate with thaghut, because the faith of believer cannot be unambiguous; faith in the book of Allah and the Evil's Judges. If they deliberate to thaghut, it means faith to the Book of Allah is unacceptable. Conversely, if he believes in the Book of Allah, he surely does not want to place a faith to thaghut. There is no partition in the hearts of the faithful.

Thaghut derives from the word "thughyan" means overreaching. A believer is forbidden to break the law when in a position as a judge with thaghut's law as limits of its powers may only use the law 
of Allah. He is also prohibited from seeking a remedy when the position of the tangled legal case law of thaghut, because the authority may only be looking for a legal settlement with the law of Allah.

This verse also gives requirements for the claim of one's faith which is recognized by Allah. The requirements are:

1. Accept the Prophet as the giver of the law when conflicts happen with society's elements, both individuals and groups as well as groups to groups. Do not turn to other than the Prophet

2. There is no objection at all when a decision has been issued. This decision could win, and also beat us. In these two possibilities, he should be gracefully because the Prophet Muhammad in the judge is guided by revelation

3. Submission and receiving on legal decisions, even it has no benefit. As the Prophet Ismail receiving his submissive must be slaughtered by his father, Ibrahim. Another example is resignation or bodies in the hands of people who bathes him and care for him. He is completely silent and he totally surrenders and does not move at all, or even protesting. Moving the tip of his finger with a single movement can stir the procession or much worse he rise up and fight against those who bathes and care for her.

The Connection between Politics of Constitutional Law and the Preaching of the Prophet Muhammad. The relationship between religion and politics continues to be a conversation that is enthusiastically discussed. Albert Hourani that the mission of the Prophet is merely a religious movement ritual, spiritual and moral (Albert Hourani, 2004: 157). However, the reality shows that the mission of the Prophet is also a political preaching. Anyone who identifies sirah of the Prophet both in the Sunnah and the Qur'an will conclude that the mission carried out by him and his Companions is not only to ritual, spiritual and moral, but also as a political preaching. Among the things are: Preaching of the Prophet. He called for the maintenance of society. Makkiyah's verses often teach something like destiny, guidance and dhalalah (health), sustenance, trust in Allah, and so on. Hundreds of verses speak of the Day of Judgment (human resurrection from the grave, human gathering in the field Mahsyar, merit and sin, heaven and hell, etc.); about settings related hereafter as advice and guidance, evokes a sense of fear of the punishment of Allah, as well as encouragement to continue to do good for the sake of reaching his Ridha.

In addition, hundreds of verses - Quran and hadith in Mecca and Medina revealed to the Prophet about setting up society in the world. For example: trading, renting, wills, inheritance, manage and divorce, obey ulil amri, correcting ruling as jihad, food and beverage, theft, grants and gifts to the ruler, murder, crime, migration, jihad, and so on. All of this confirms that what is at preach, the Prophet is not just a matter of ritual, spiritual and moral. His preaching also contains about the maintenance of society. That is, judging from the contents of Prophet's preaching is also political. Prophet also gives thought. This thought and understanding of Arab society at that time was under the critics. Therefore, there was a struggle. Finally, thoughts and understanding of Islam can replace the old ones. Consequently, laws that are applied in society have changed.

The Prophet, with Al-Quran in hand, attacked kufr, envy, trusting in idols, distrusting of the Day of Resurrection, the assumption Prophet Isa as God's children, etc. Wisdom, advice, and debate are well kept conducted by Prophet.

Al - Quran perpetuate this: (An-Nahl [16]:125)

Invite (all) to the Way of thy Lord with wisdom and beautiful preaching; and argue with them in ways that are best and most gracious: For thy Lord knoweth best, who have strayed from His Path, and who receive guidance.

Obviously, this is a political activity because it is indeed the activity of ri'ayah syu'un al - umma, managing the affairs of the society. 
After having emigrated from Mecca to Medina, which is Yathrib he established political institutions such as the State of Medina. He immediately takes care of the affairs of the society, for instance in the field of education. He sets a ransom captive in Badr War by teaching reading and writing to ten Muslims. In the matter of job, the Prophet issues capital policy with giving the fund and provides employment like firewood for sale. (HR Muslim and Ahmad). The Prophet sets a policy regarding the distribution of the water for agriculture (Bukhari and Muslim). Thus, The Prophet, as the head of government, has been providing direction in dealing with people's problems.

Directly, the Prophet Muhammad points Ali bin Abi Thalib as a writer (scribes) any international treaties and agreements, Harith bin Auf as stamp holder of head of state (some rings) of the Prophet. Muaiqib bin Abi Fatimah as assessor of booty (ghanimah), Hudzaifah bin Yaman as head of the statistical results center of fruits in Yemen, etc.

Based on the act of the Prophet's preaching and the Companions, it is clear that he is not merely preaching that include rituals, spiritual and moral but also His preaching has politic elements; taking care of the affairs of the society with Shari'a. Therefore, the preaching of Islam should be directed as does he. Politics can not and should not be separated from Islam. Of course, the intended politics is not the type of Machiavellian.

\subsection{Politics of Constitutional Law and Dakwah," Amar Ma'ruf Nahi Munkar"}

Basically, preaching is the sacred duty of Muslims that are identical to the primary mission of the Prophets and Messengers. Al Quran and As-Sunnah have described the importance of preaching in upholding the religion of Allah on earth. Historically, preaching occupies an important position, the central strategic and it has a crucial point in the process of resurrection and glory of Islamic civilization. Preaching is extremely important to personal and social life of the people, so it becomes a center of attention, studies and activities that will be going from generation to generation.

Preaching in a generic sense is meant as an invitation, a call to the truth (al-haqq) and policies (al-khair), or orders to the kindness and prevents what is wrong. This activity can be done orally, in writing or by deed, and can be done individually or in groups in the organization of preaching as a collective obligation of Muslims.

Meanwhile, according to some preachers and experts in the science of preaching such as Shaykh 'Ali Mahfouz (1880-1942 AD), state that the mission in order to encourage and motivate people to do right and follow the instructions and tell them to do right and prevent the unjust actions, so that they will be able to have happiness in the world as well as hereafter (Ali Mahfouz, 1952: 16).

More specifically, according to Abd Munir Mulkhan, the aim of preaching is that people change from one situation to another situation that is better in all aspects of living with the goal of realizing Islam's teaching in the reality of daily life, both for subsistence with the aim of realizing Islam's teaching in the reality of daily life and for livelihood of an individual, family and society that all lives in togetherness (Abdul Munir Mulkan, 1993: 100).

From that definition, it shows that the word "dakwah" is often associated with the word commanding the good and forbidding what is forbidden, inviting to good and forbidding what is wrong. In other words, "dakwah" is as an attempt to build a better life and well-maintained human's life from the things that can cause damage, disruption, and destruction. With such an understanding, it is not only positioned as an effort to increase religious understanding and life's perception, but also includes a broader target, namely the implementation of Islamic teachings as a whole parts (kaffah) in various aspects of human's life, which also includes economic, social, politics and so on, with the purpose for 
relizing a good, balanced, and dignified life, so that people will have happiness in the world and hereafter.

Preaching is a series of activities or processes in order to achieve that noble aim. The aim is at least to give directions or guidelines for preaching activites, because without a clear aim throughout preaching activities will lose the soul and spirit of struggle. More broadly, the aim of preaching based on Messenger's missions from time to time is always the same; a calling to the path of Allah, invite all people to worship only to Allah, as well as give an understanding of good faith, and motivate people to adhere to the teachings of Allah and His Messenger daily life, so it will create a faithful, well educated and qualified individuals (Khoirul al fardiyah), a harmonious family (khairu al usrah), a tough community (umma kkairu) and eventually formed a nation and a prosperous developed country in terms of Al Quran baladatun thoyyibatun wa robbun ghofur (Wahidin Saputra, 2011: 9)

In general, the word "ma'ruf" can be interpreted as either something seen, or ordered by syara, while the word "munkar" is something that is seen as bad, forbidden or hated by syara '. However, in broader scope, al ma'ruf can be interpreted as good (al khair) that is universally recognized, called Islam. Al Munkar can be understood as anything that naturely rejected or hated by the human conscience. Then the both words indicate the reality of good and evil in society. (Ramli Ridwan, 2001: 145).

There is an assertion that in the face of bad deeds must be done collectively. It is like an explanation of hadith of the Prophet (Muslims, pp 45-46):

"Whoever looks bad deeds, let him change it with his hand (power) and if he is unable, let him change it with his tongue, and if he is unable, let him change it with his heart and that is the least of one's faith".

In this context, Sayyid Qutb (1906-1966 AD) stated that al-amr bi al-ma'ruf wa al nahy'an almunkar are the two main tasks of Muslims to uphold manhaj of Allah in the world in order to win the truth and overcome any bad seed (Sayyid Qutb, tt: 184). Meanwhile, according to Yusuf al-Qaradawi, those two tasks are fundamental obligation in Islam, which is why Allah gives more advantages and virtues to Muslims rather than other believers. (Yusuf al Qardawiy, 1993: 51)

Furthermore, Sayyid Quthub stressed that there should be a power in the management of preaching. This happens because the activities of al-amr bi al-ma'ruf wa al - nahy 'an al-munkar has a command to the right and to the banned things. It shows that the manhaj of Allah in the world is not limited to advice, guidance and teaching, but further it includes aspects of the power to enforce the rule and prohibit the regulation, to make the right comes true and take the bad deeds off in human's life and habbits, to maintain good deeds, to carry out the commands of Allah and to keep away from bad habits in society(Sayyid Qutb, tt: 124)

In practice, al-amr bi al ma'ruf was easier to apply compared to al- nahy 'an al-munkar. The problems encountered in enforcing something "makruf" (good deeds) is not as much as forbidding something "mungkar" (unjust). Therefore, in establishing goodness or forbidding what is wrong must deal with knowledge and wisdom.

According to Yusuf al Qaradawi, when stopping the bad deeds, we should pay attention to the following conditions. First, bad deeds (kemungkaran) is an agreed case in term of forbidden thing. Doing something that is "makruh" or leaving something that is "sunnah", is not considered as bad deeds (mungkar). A case which forbade by nas-nas syara' or Qat'I considered as mungkar. Second, bad deeds can be seen clearly. Bad deads which is concealed by the perpetrators of the eyes of others should not be looking for finding the bad deeds that are not true yet. Third is having the power to change bad deeds (mungkar) (Yusuf al Qaradawiy, tt: 52). 
Based on the description above, the rule of amr maruf nahi munkar requires an understanding of the concept very well and the depth as well as wisdom in its application. Therefore, the implementation of amr maruf nahi munkar requires an ability to understand the texts of the Qur'an and as-Sunna, plus the ability to understand the social environment, politics, and culture as a forum for the realization of real kindness. Besides, prevention the bad deeds requires the ability to identify environmental factors that can potentially be a platform for emerging and developing acts contrary to conscience. Therefore, the process and missionary activity should be able to see and understand good and bad deeds which is in the middle of society, so that ultimately the purpose of preaching can be realized.

\subsection{POLITICS OF CONSTITUNIONAL LAW AS A PREACHING'S INSTRUMENT.}

Preaching that have mentioned above is an activity to reconstruct society according to Islam's lessons. So that all aspects of human life is the arena of preaching. To realize the preaching in every form of human activity, then the whole of human activity or profession is also a means or instrument of Islam. The responsibility is not only the task of preacher but it is also the duty of economists, politicians and rulers of other professions. They also have an obligation and responsibility to carry out preaching according to its capabilities for themselves.

There is no doubt that the political and preaching have a very close relationship in the Islamic perspective. Prophet Muhammad in Medina have delivered examples of how to play a role in the development of Islam. Political matters of constitutional law concerning the power and the means to use power. In practice, politics is always associated with the manner and process of governance in a country. Therefore, politics is one of the most important activities in the society, because almost all the people in the world live in a political system of constitutional law. Politics of constitutional law has an important role in determining the style and form settings social life, economy, culture, law and various aspects of society's life.

In that context, it is interesting to follow the line of Ibn Khaldun's thought. According to him, the government would be more authoritative if the implementation of power is carried out based on religious values. Moreover, it will survive in its execution to follow the values of truth because the human heart can only be joined together with the help of God (Akbar Ahmed, 2002:25).

The power that is based religion would be strong because of the support of the people. In addition, religion can defuse conflict in the society and a sense of envy for the realization of true brotherhood (Charles Issawi, 1976: 180). Therefore, the true political activity is based on religion that is truly from $\mathrm{Al}$ Quran and Hadith. Politics does not walk alone without guarded by religion and not separate them with preaching. The reality today is that the mission carried out by experts and preachers, while the political power of constitutional is done by Sultan, King or president. This leds to the separation between the implementation of political and preaching. The prophet Muhammad and al-Rashidah khulafa never separate the political practice of constitutional law with missionary activity though.

Prophet Muhammad in carrying his message can not be separated from political practice of constitutional law to implement what is right and wrong. This suggests that the political function in the spread of religion is relevant and important in practice. Religion and politics have a connection which is difficult to separate. Because world's life is not only for the world merely, but the world must be able to bring every Muslim to be happy in the hereafter.

World's life is not the ultimate goal of human life. Life on earth is only one-half life towards the hereafter. The doctrine of political Islam is concerned with the life of the world. Due to that phenomena, Imamah is a legacy left by the Prophet, to carry out the rule of Allah for the realization of mankind's peacefulness in the world and hereafter. 
According to Amien Rais, political activity of constitutional is considered good if it gives benefit of all the people and in accordance with the concept of universal grace or in the words of Al Quran. Furthermore, he states that politics must be understood in three categories. First, as a political mandate from the people which should run as well as possible. Second, political activity of constitutional law must be accountable to Allah. Third political activities should be in line with the principles of brotherhood in Islam

\subsection{THE POLITICAL ROLE OF CONSTITUTIONAL LAW IN PREACHING.}

Intersection between political political and constitutional law happens when the institutional preaching and politics of constitutional law tried to put together. For instance, a political party that has double function as a propaganda agency. Such this political mode not only makes ambiguity in the status of the institution concerned political parties, but also creates friction and conflict with Islamic organizations since the beginning of choosing the path of preaching, not practical politics of constitutional law. Here politics and preaching of constitutional law seemed like an unequal world, both in the principles, values, and methods. Therefore, the relationship will produce patterns and different conclusions, depending on how to place and apply them, whether preaching in politics of constitutional law or politics of constitutional law in preaching.

If preaching is placed in the politics of constitutional law, it will become an instrument of preaching and a means by which to achieve the political goals of the party concerned. Preaching is subordinate to political interests, and that is why, it is prone to be abused. In politics, there is no way for them to have no interest in power. Hence, the aim of preaching of political parties is for political purposes of constitutional law, such as to seize or maintain power.

Such a friction is often happened with Islamic organizations since preaching's party's becaome an expansion into the organization and life of the congregation Islamic organizations, such as through the study and management of the mosque. Likewise, when a natural disaster strikes, help and donations are managed by the usual political figure with condition, having a special party's member card. The help is often claimed by other parties or given the stamp of Islamic parties concerned.

In fact, as asserted by Muhammad Natsir, preaching and akhlaqul kharimah are two things that can not be separated from each other (Muhammad Nasir, 2008: 16). Politics is not just a battle for gaining power like the quote of C. Calhoun, "The ways in which people gain, use, and lose power". Politics of constitutional law also relates to a process and system that go to make government policy and legislative decisions in favor of the interests of the people and the sovereignty of the state and the nation. The policies and attitudes of different political parties preaching are an endeavor to appreciate the politics and preaching proportionately.

With proper placement, the relationship between preaching and politics can be understood in two ways, as follows:

1. Restore the meaning of preaching on the substance of value and principle as outlined by Allah (QS Al Imron : 104 and 110; An-Nahl: 125; Fushilat)

2. Preaching should be done in all aspects of human's life. For example, every Muslim politician who deals in politics should conduct to preaching, but it is not preaching for political purposes of constitutional law.

This case has been an example and role model in the political world of constitutional law that the values of honesty, attention to the people, simplicity, nobility and glory can color the behavior of politicians and administrators in the society, state and nation. The right and proper political preaching is not politicized preaching, because preaching has been very clear meaning contained in the Al Qur'an. 
God has set a treatise of human creation, which serve Him, then make caliph in order to build prosperity on earth for the peacefulness of humans and the universe. In order for this treatise becomes true in the history of human civilization, Allah manipulates it in the life, so it has a relationship interaction "positive" and "negative" among all the creatures in general, and mankind particularly. What the meaning of positive interaction is, an association of helping each other. Moreover, the negative interaction is the relationship of war and hostility between mankinds. Allah says (Al Baqarah 251).

They routed them: and Dawud slew Jalut; and Allah gave him power and wisdom and taught him whatever (else) He willed. And did not Allah Check one set of people by means of another, the earth would indeed be full of mischief; but Allah is full of bounty to all the worlds.

That immortality treatise is highly dependent on the outcome of each interaction both positive and negative. If you are helping the faithful man, which in turn they help each other in goodness and devotion; and if it is in battle, won also by the faithful man, then surely that will happen is immortality treatise. But if you are helping poor people who agree to carry out the crime and hostility, and then they too were winning the war, then surely that will happen is the destruction.

Here lies the role of political preaching. Preaching invites to goodness, implements treatise of human creation, calls on the right and prevents all forms of bad deeds, while politics plays provide motivation, protection, security, and protection facilities for the realization of that treatise.

\subsection{PREACHING'S FACILITY STRAIGHTENS POLITICS OF CONSTITUTIONAL STAGE}

It was mentioned earlier that politics is viewed as efforts to achieve prosperity and welfare for all humans. However, in practice it is often sacrificed for the interest of the public just a power struggle and political interests merely. Therefore, politics in practice should be based on a universal value that is able to control politics in order not to get out of his goal. In this case if it is based on Islamic values, the politics practiced in the middle of the society can be classified into two: the high and law politics of constitutional law.

There are at least three characteristics that must be owned by a high-quality policy or by those who permit the implementation of high politics. First, every political office in the form of a public trust has to be maintained as well as be possible and be accountable to the people and Allah. That trust should not be abused, such as corruption to enrich themselves or their own group's interests and ignoring the public interest. Second, political activities must be linked closely with the principle Ukhwah and tolerance; brotherhood among the human beings and respect for human dignity, respect for differences such as ethnic, racial, religious, social background, descent and so forth. High politic of constitutional quality is expected to avoid a confrontational political style that is full of conflict and see the other party as a party that should be eliminated. Third, the political activities of constitutional law should promote the interests of religion and the state over all existing interests (Muhammad Iqbal, 2001: 20)

While low quality in politics of constitutional law practiced inconsistent with the purposes of preaching, but they inhibit proselytizing, deprave Islamic society instead. Here are the characteristics of low quality politics: politics first tends to have a violence, cruelty and coercion done by the authorities or to justify a variety of ways to achieve the goal of state or political interests.

Second, make the enemy of legal political parties becomes the dense destabilizing power, so that they must be destroyed or killed. Third, running the political life of a ruler should be able to play like "wild ones", in the sense that there is no tolerance for those who oppose the rule in any state policy. 
Paisol Burlian / UMRAN - International Journal of Islamic and Civilizational Studies. vol. 4, no. 1 (2017) 80 - 90

\subsection{INTEGRATION BETWEEN PREACHING AND CONSTITUTION POLITICS}

Based on the lecture above, it has given a clear picture of the legal political system that the State has a special place in Islam. Islam as a universal teaching clearly and unequivocally does not separate the religious and the world issues of political governance laws of the State. Even political state of constitutional law is considered as a way to elevate wasilah or religion and preaching in the middle of the society. It is also in line with the opinion of Ibn Taymiyyah and al Mawardi that politics should be used for the purpose and importance of religion or preaching.

Politics (Siyasah) generally means something related to power and how to use it. Power has achieved if there are agencies, namely the State as a means to apply power separately. Political State of constitutional law in the Islamic tradition has a close relationship with the government management in the care of the interests of the community and brings them to the benefit and minimizes the bad deeds, so it is in line with the political purpose of preaching. However, in practice, it is often using political or religious' view for the benefit of the political state of constitutional law. Essentially, according to the Islamic concept, the politics is rather than being a tool to develop and succeed preaching. According to Ali Sodiqin that the strategy of delivering, the preaching can not be separated from efforts to build political strength of Muslims and the power of politics as well as the spread of a unified and synergistic religion.

One of the forms of political preaching can be seen through the close relationship between the preachers and the ruler or government. Ideally, the relationship is reciprocal and mutually beneficial to both parties in the context of preaching and politics. Ruler gives space for preaches, and they give religious legitimacy to the ruler. This condition has actually occurred throughout the history of Islam.

Islamic politics contributed simbiosism thoughts concerning religion and politics. Thought of the pre -modern tended to be under the direction of politics into religion, and vice versa; modern paradigm, which is under the direction of religion into politics. Pre-modern paradigm tends to politicize religion. Politics of Islam in this case takes the form of the appearance or formation of ideas and political institutions to justify the ongoing political process.

Making preaching as a political tool is something that has not been authenticated. Preaching must be in the position of the free dimension and there is no monopoly or subsosial of the particular institution or political power. Instead, the preaching should be a portion of the various parties; the State, organizations, institutions, and political parties, to enforce commanding amr ma'ruf nahi munkar. It is based on the idea that the history of preaching was older than universal politics and preaching.

Preaching as a commandment of Allah SWT should be more enduring than the society, state and even political culture. Therefore, it should be used as an instrument of political preaching. There is no principle that prohibits Naqli which establish political parties based on religion. Intention to establish political parties to establish the religion is something legitimate. Due to a variety of worldly interests, politics often deviate from the original purpose. Politics by its relativism, it easily becomes soluble in the term of interest, especially for the benefit of voters, so that political decisions are very concerned constituency. In other words, a politician becomes a representative of people who choose him. While role in preaching, it is not the main goal, but the values of truth are taken from Al-Quran and Sunnah which have to be delivered.

\subsection{CONCLUSION}

Preaching and politics of law are two things that can provide mutua-symbiotic, which is then the meaning of the two merged in terms of political preaching of State constitutional law or political 
preaching. Due to the use of political power in constitutional law of the State, then the goal will be more quickly realized, and politics is inserted in the preaching, so that Islam has given how do politics correctly, which does not interfere with the interests of others, not slander nor knockdown, and the political significance in the Islamic view is contrary to the political significance of the western state constitutional law that justifies any means to achieve goals.

With two contrast views of politics in constitutional law, Islam can show Rahmatan Lil Alamin to the world, and the merger between political preaching and politics of constitutional law is quickly realized like what Prophet did in Medina which differs when the prophet preached in Mecca.

\section{REFERENCES}

Abdul Ghafar Don. (2005) "Integrasi Politik dan Dakwah” dalam Zulkiple Abd. Ghani dan Mohd. Syukri Yeoh Abdullah (ed), Dakwah dan Etika Politik di Malaysia, Kuala Lumpur: Utusan Publication dan Distributors Sdn Bhd.

Abdul Munir Mulkhan. 1993). Paradigma Intelektual Muslim. Yogyakarta: Sipress.

Abdullah. (2012). Dakwah Kultural dan Struktural: Telaah Pemikiran dan Perjuangan Dakwah HAMKA dan M. Natsir. Bandung: Citapustaka Media Perintis.

Abdullah. (2002). Wawasan Dakwah: Kajian Epistemologi, Konsepsi dan Aplikasi Dakwah. Medan IAIN Press.

Ali Mahfuzh. (1952). Hidayah al-Mursyidin. Al-Qahirah: Dar al-Kitabah,

Al-Banna, Hasan. (1983). Majmu'ah ar-Rasail Hasan al-Banna, al-Muassasah al-Islamiyah Beirut.

Jurdi, Syarifuddin. (2008). Pemikiran politik Islam Indonesia, Pertautan negara, khilafah, masyarakat madani dan demokrasi. Pustaka Pelajar: Bulak Sumur.

Jum‘ah Amin ‘Abd al-‘Aziz. (1997). Fiqh-Dakwah. (Terj.) Abdus Salam Masykur. Solo: Citra Islami Press.

Hourani, Albert. (2004). Pemikiran Liberal di Dunia Arab, Bandung: Mizan.

Iqbal, Muhammad (2001). Fiqh Siyasah Kontekstualisasi Doktrin Politik Islam. Jakarta: Gaya Media Pratama, Cet I.

M. Amien Rais. (1991). Cakrawala Islam: Antara Cita dan Fakta, Bandung: Mizan.

Natsir, Muhammmad. (2008). Politik Melalui Jalan Dakwah, Jakarta: Media Dakwah.

Wahidin Saputra. (2011). Pengantar Ilmu Dakwah. Jakarta: Raja Grafindo Persada.

Taimiyah, Ibnu. (1969). al-Siyasah al-Syar'iyyah Ishlah al-Ra'i Wa al-Ra'iyyah, Mesir, Dar al-Kitab al-Arabi.

Taufiq Yusuf Al-Wa'iy. (2003). Pemikiran Politik Kontemporer Al-Ikhwan Al-Muslimun : Studi Analitis, Observatif, Dokumentatif. Solo: Era Intermedia.

Yusuf al Qardawiy. (1993). Anatomi Masyarakat Islam. (Terj.) Setiawan Budi Utomo. Jakarta: Pustaka al-Kautsar. 